\title{
KAJIAN HUKUM TERHADAP TINDAK PIDANA PENIPUAN DENGAN DASAR HUTANG PIUTANG
}

\author{
Oleh: \\ Syawal Amry Siregar \\ Kristofel Ablio Manalu \\ Universitas Darma Agung, Medan \\ E-mail: \\ syawalamrysiregar@gmail.com \\ kristofelabliomanalu@gmail.com
}

\begin{abstract}
The form of responsibility for the perpetrator in a criminal act of fraud on the basis of accounts payable is to follow the existing procedures, from the investigation process to the detention process. This research method is normative juridical. The formulation of the problem under study is what is the form of fraud on the basis of accounts payable; What is the form of legal protection for victims of criminal cases of fraud on the basis of accounts payable and what is the form of accountability of the perpetrators for criminal acts of fraud on the basis of accounts payable. The result is a form of fraud on the basis of accounts payable, including the criminal act of fraud in the Criminal Code regulated in Book II concerning Crimes against Assets, which is in the form of attacks on people's legal interests for their property and fraud on the basis of accounts payable related to money lending and borrowing problems (accounts payable),
\end{abstract}

Keywords; Accounts Payable, Criminal Liability, Fraud

\begin{abstract}
ABSTRAK
Bentuk pertanggungjawaban pelaku dalam tindak pidana penipuan dengan dasar hutang piutang adalah mengikuti prosedur yang ada, dari mulai proses penyidikan sampai proses penahanan. Metode penelitian ini adalah yurid is normative. Adapun rumusan masalah yang diteliti adalah Bagaimana bentuk tindak pidana penipuan dengan dasar hutang piutang; Bagaimana bentuk perlindungan hukum terhadap korban atas kasus tindak pidana penipuan dengan dasar hutang piutang dan Bagaimana bentuk pertanggungjawaban pelaku atas tindak pidana penipuan dengan dasar hutang piutang. Adapun hasilnya adalah Bentuk tindak pidana penipuan dengan dasar Hutang Piutang antara lain tindak pidana penipuan dalam KUHP diatur pada Buku II tentang Kejahatan terhadap Harta Kekayaan, yaitu berupa penyerangan terhadap kepentingan hukum orang atas harta benda yang dimilikinya dan tindak pidana penipuan dengan dasar hutang piutang terkait dengan masalah pinjam meminjam uang (hutang piutang),
\end{abstract}

Kata Kunci; Hutang Piutang, Pertanggungjawaban Pidana, Tindak Pidana Penipuan 


\section{PENDAHULUAN}

\section{A. Latar Belakang}

Hutang piutang merupakan persoalan yang lazim dilakukan oleh semua kalangan masyarakat. Hutang piutang merupakan menitikberatkan kepada uang atau barang yang dipinjamkan kepada seseorang dengan kewajiban untuk mengembalikan uang atau barang tersebut sesuai dengan perjanjian atau apa yang sudah disepakati sesuai dengan perjanjian. Secara singkat, hutang piutang itu memberikan sesuatu kepada orang lain dengan perjanjian bahwa dia akan membayar atau mengembalikan dengan semestinya.Namun, belakangan ini sangat banyak tindakan atau laporan pengaduan terhadap tindak pidana berdasarkan penipuan hutang piutang. Hutang piutang biasanya berkaitan dengan proses gadai sebagai jaminan atas apa yang dihutangkan sebagai bentuk bahwa pertanggung jawaban pemiutang untuk melunaskan hutangnya, seperti contoh-contoh yang dijelaskan dalam buku "Hukum Jaminan, hak-hak jaminan kebendaan"

Kejahatan termasuk penipuan merupakan gejala sosial yang senantiasa dihadapi oleh setiap masyarakat di dunia ini. Kejahatan dalam keberadaannya dirasakan sangat meresahkan, disamping itu juga mengganggu ketertiban dan ketentraman dalam masyarakat berupaya semaksimal mungkin untuk menanggulangi kejahatan tersebut.

\section{B. Rumusan Masalah}

1. Bagaimana bentuk tindak pidana penipuan dengan dasar hutang piutang?

2. Bagaimana bentuk perlindungan hukum terhadap korban atas kasus tindak pidana penipuan dengan dasar hutang piutang ?

3. Bagaimana bentuk pertanggungjawaban pelaku atas tindak pidana penipuan dengan dasar hutang piutang?

\section{Tujuan Penelitian}

1. Untuk mengetahui bentuk tindak pidana penipuan dengan dasar hutang piutang.

2. Untuk mengetahui bagaimana bentuk perlindungan hukum terhadap korban atas kasus tindak pidana penipuan dengan dasar hutang piutang.mengetahui bentuk pertanggungjawaban pelaku tindak pidana penipuan dengan dasar hutang piutang.

3. Untuk mengetahui pertanggungjawaban pelaku atas tindak pidana penipuan dengan dasar hutang piutang.

\section{METODE PENELITIAN}

Menggunakan metode yuridis normative, yakni mengkaji kepustakaan.

\section{Jenis dan Sumber Data}

Jenis dan sumber data yang akan digunakan yaitu :

Data sekunder, yaitu data yang diperoleh melalui studi kepustakaan terhadap berbagai macam bahan bacaan yang berkaitan dengan obyek kajian seperti literature-literatur, dokumen, putusan hakim tentanmaupun sumber lainnya yang berkaitan dengan masalah dan tujuan penelitian.

\section{Teknik Pengumpulan Data}

Pengumpulan data dilakukan dengan 2 (dua) cara yaitu : Metode penelitian kepustakaan, penelitian ini penulis lakukan dengan membaca serta mengkaji berbagai literature serta putusan yang 
relevan dan berhubungan dengan masalah penelitian yang dibahas sebagai landasan teoritis.

\section{Analisis Data}

Data-data yang telah diperoleh baik data primer maupun data sekunder kemudian akan dianalisis agar menghasilkan kesimpulan. Kemudian hasil akan disajikan secara deskriptif, sehingga dapat memberikan pemahaman yang jelas dan terarah dari hasil penelitian nantinya.

\section{HASIL PENELITIAN DAN} PEMBAHASAN

\section{A. Bentuk Tindak Pidana Penipuan} Dengan Dasar Hutang Piutang

Tindak pidana penipuan yang diatur dalam buku II bab XXV Pasal 378 - 395 KUHP. Pasal-pasal tersebut menjelaskan tentang jenis-jenis tindak pidana penipuan dalam KUHP yaitu :

1. Pasal 378 KUHP mengenai tindak pidana dalam bentuk pokok

2. Pasal 379 KUHP mengenai tindak pidana penipuan ringan. Kejahatan ini merupakan bentuk penipuan dengan unsur-unsur yang meringankan.

3. Pasal 379 a KUHP merupakan bentuk pokok yang disebut penarikan botol (Flessentrekkerij) yang mengatur tentang tindak pidana kebiasaan membeli barang tanpa membayar lunas harganya. Unsur dari Flessentrekkerij adalah unsur menjadi sebagai mata pencaharian atau sebagai kebiasaan.

4. Pasal 380 ayat $1-2$ KUHP yaitu tindak pidana pemalsuan nama dan tanda atas seusatu karya ciptaan orang. Pasal ini dibuat bukan untuk melindungi hak cipta seseorang, melainkan untuk melindungi konsumen terhadap perbuatanperbuatan yang bersifat menipu oleh orang-orang tertentu.

5. Pasal 381 KUHP mengenai penipuan pada pertanggungan atau perasuransian.

6. Pasal 382 KUHP mengatur tindak pidana yang menimbulkan kerusakan pada benda yang dipertanggungkan.

7. Pasal 382 bis KUHP mengatur tindak pidana persaingan curang atau oneerlijke mededinging.

8. Pasal 383 KUHP mengatur tindak pidana penipuan dalam jual beli

9. Pasal 383 bis KUHP mengatur penipuan dalam penjualan beberapa salinan (copy) kognosement.

10. Pasal 384 KUHP mengatur tindak pidana penipuan dalam jual beli dalam bentuk geprivilegeerd.

11. Pasal 385 KUHP mengatur tentang stellionet yaitu tentang tindak pidana penipuan yang menyangkut tanah.

12. Pasal 386 KUHP mengatur penipuan dalam penjualan bahan makanan dan obat.

13. Pasal 387 KUHP mengatur penipuan terhadap pekerjaan pembangunan atau pemborongan.

14. Pasal 388 KUHP mengatur penipuan terhadap penyerahan barang untuk angkatan perang.

15. Pasal 389 KUHP mengatur penipuan terhadap batas pekarangan.

16. Pasal 390 KUHP mengatur tindak pidana menyebarluaskan berita bohong yang membuat harga barang-barang kebutuhan naik.

17. Pasal 391 KUHP mengatur penipuan dengan memberikan gambaran tidak benar tentang surat berharga. 
18. Pasal 392 KUHP mengatur penipuan dengan penyusunan neraca palsu.

19. Pasal 393 KUHP mengatur penipuan dengan pemalsuan nama firma atau merk atas barang dagangan.

20. Pasal 393 bis KUHP mengatur penipuan dalam lingkungan pengacara.

21. Pasal 394 KUHP mengatur penipuan dalam keluarga.

22. Pasal 395 KUHP mengatur tentang hukuman tambahan.

Unsur-unsur tindak pidana penipuan juga dikemukakan oleh Togat sebagai berikut :

1. Unsur menggerakkan orang lain ialah tindakan-tindakan, baik berupa perbuatan-perbuatan mupun perkataan-perkataa yang bersifat menipu.

2. Unsur menyerahkan suatu benda. Menyerahkan suatu benda tidaklah harus dilakukan sendiri secara langsung oleh orang yang tertipu kepada orang yang menipu. Dalam hal ini penyerahan juga dapat dilakukan oleh orang yang tertipu itu kepada orang suruhan dari orang yang menipu.

3. Hanya dalam hal ini, oleh karena unsur kesengajaan maka ini berarti unsur penyerahan haruslah merupakan akibat langsung dari adanya daya upaya yang dilakukan oleh si penipu.

4. Unsur memakai nama palsu. Pemakaian nama palsu ini akan terjadi apabila seseorang menyebutkan sebagai nama suatu nama yang bukan namanya, dengan demikian menerima barang yang harus diserahkan kepada orang yang namanya disebutkan tadi.
5. Unsur memakai martabat palsu. Dengan martabat palsu dimaksudkan menyebutkan dirinya dalam suatu keadaan yang tidak benar dan yang mengakibatkan si korban percaya kepadanya, dn berdasarkan kepercayaan itu ia menyerahkan suatu barang atau memberi hutang atau menghapus piutang.

6. Unsur memakai tipu muslihat dan unsur rangkaian kebohongan. Unsur tipu muslihat adalah rangkaian kata-kata, melainkan dari suatu perbuatan yang sedemikian rupa, sehingga perbuatan tersebut menimbulkan keprcayaan terhadap orang lain.Sedangkan rangkaian kebohongan adalah rangkaian kata-kata dusta atau kata-kata yang bertentangan dengan kebenaran yang memberikan kesan seolaholah apa yang dikatakan itu adalah benar adanya.

Berdasarkan semua pendapat yang telah dikemukakan tersebut diatas, maka seseorang baru dapat dikatakan telah melakukan tindak pidana penipuan sebagai mana dimaksud dalam Pasal 378 KUHP, apabila unsur-unsur yang disebut di dalam pasal tersebut telah terpenuhi, maka pelaku tindak pidana penipuan tersebut dapat dijatuhi pidana sesuai perbuatannya.

Pasal 378 KUHP tentang tindak pidana penipuan merumuskan, yaitu:

"Barangsiapa dengan maksud menguntungkan diri sendiri atau orang lain secara melawan hukum dengan memakai nama palsu atau martabat palsu, dengan tipu muslihat, ataupun rangkaian 
kebohongan, menggerakkan orang lain untuk menyerahkan barang sesuatu kepadanya, atau supaya memberi utang maupun menghapuskan piutang, diancam karena penipuan dengan pidana penjara paling lama empat tahun".

Dari rumusan Pasal 378 KUHP di atas, maka unsur tindak pidana penipuan seperti pada umumnya tindak pidana terdiri dari unsur objektif dan subyektif. Unsur subyektif meliputi maksud menguntungkan diri sendiri atau orang lain dan melawan hukum. Unsur objektif yang meliputi perbuatan (menggerakkan), yang digerakkan (orang), perbuatan itu ditujukan pada orang lain (menyerahkan benda, memberi hutang, dan menghapuskan piutang), dan cara melakukan perbuatan menggerakkan dengan memakai nama palsu, memakai tipu muslihat, memakai martabat palsu, dan memakai rangkaian kebohongan.

Berikut merupakan penjelasan singkat terkait unsur subyektif dan unsur objektif tindak pidana penipuan, yaitu:

a. Unsur subyektif, yaitu:

1) Maksud untuk menguntungkan diri sendiri atau orang lain

Dalam hal ini maksud si pelaku dalam melakukan perbuatan menggerakkan harus ditujukan pada menguntungkan diri sendiri atau orang lain, yakni berupa unsur kesalahan dalam penipuan. Terhadap sebuah kesengajaan harus ditujukan pada menguntungkan diri, juga ditujukan pada unsur lain dibelakangnya, seperti unsur melawan hukum, menggerakkan, menggunakan nama palsu dan lain sebagainya. Kesengajaan dalam maksud ini harus sudah ada dalam diri si pelaku, sebelum atau setidak-tidaknya pada saat memulai perbuatan menggerakkan. Menguntungkan artinya menambah kekayaan dari yang sudah ada. Menambah kekayaan ini baik bagi diri sendiri maupun bagi orang lain.

2) Dengan melawan hukum

Dalam hal ini unsur maksud sebagaimana yang diterangkan di atas, juga ditujukan pada unsur melawan hukum. Maksud menguntungkan diri sendiri atau orang lain dengan melakukan perbuatan menggerakkan haruslah berupa maksud yang melawan hukum. Unsur maksud dalam rumusan penipuan ditempatkan sebelum unsur melawan hukum, yang artinya unsur maksud itu juga harus ditujukan pada unsur melawan hukum. Dalam hal ini sebelum melakukan atau setidaktidaknya ketika memulai perbuatan menggerakkan, pelaku telah memiliki kesadaran dalam dirinya bahwa menguntungkan diri sendiri atau orang lain dengan melakukan perbuatan itu adalah melawan hukum.

b. Unsur obyektif

1) Unsur barangsiapa

Yang dimaksud dengan barangsiapa adalah orang yang melakukan perbuatan penipuan, yang mana terhadap perbuatan dan orang yang melakukan tindak pidana penganiayaan itu dapat dipertanggungjawabkan. 
2) Unsur perbuatan menggerakkan

Kata menggerakkan dapat juga diartikan dengan istilah membujuk atau menggerakkan hati. Dalam KUHP sendiri tidak memberikan keterangan apapun tentang istilah menggerakkan. Menggerakkan dapat didefinisikan sebagai perbuatan mempengaruhi atau menanamkan pengaruh pada orang lain, karena objek yang dipengaruhi yakni kehendak seseorang. Perbuatan menggerakkan juga merupakan perbuatan yang abstrak, dan akan terlihat bentuknya secara konkrit bila dihubungkan dengan cara melakukannya, dan cara melakukannya inilah sesungguhnya yang lebih berbentuk, yang bisa dilakukan dengan perbuatan-perbuatan yang benar dan dengan perbuatan yang tidak benar. Karena di dalam sebuah penipuan, menggerakkan diartikan dengan cara-cara yang di dalamnya mengandung ketidakbenaran, palsu dan bersifat membohongi atau menipu.

3) Yang digerakkan adalah orang

Pada umumnya, orang yang menyerahkan benda, orang yang memberi hutang dan orang yang menghapuskan piutang sebagai korban penipuan adalah orang yang digerakkan itu sendiri. Tetapi hal itu bukan merupakan keharusan, karena dalam rumusan Pasal 378 KUHP tidak sedikitpun menunjukkan bahwa orang yang menyerahkan benda, memberi hutang maupun menghapuskan piutang adalah harus orang yang digerakkan. Orang yang menyerahkan benda, memberi hutang maupun menghapuskan piutang bisa juga oleh selain yang digerakkan, asalkan orang lain atau pihak ketiga menyerahkan benda itu atas perintah atau kehendak orang yang digerakkan.

4) Tujuan perbuatan

Tujuan perbuatan dalam sebuah penipuan dibagi menjadi 2 (dua) unsur, yakni:

a) Menyerahkan benda

Dalam hal ini pengertian benda dalam penipuan memiliki arti yang sama dengan benda dalam pencurian dan penggelapan, yakni sebagai benda yang berwujud dan bergerak. Pada penipuan benda yang diserahkan dapat terjaditerhadap benda miliknya sendiri asalkan di dalam hal ini terkandung maksud pelaku untuk menguntungkan diri sendiri atau orang lain.

b) Memberi hutang dan menghapuskan piutang

Dalam hal ini perkataan hutang tidak sama artinya dengan hutang piutang, melainkan diartikan sebagai suatu perjanjian atau perikatan. Yang dimaksud dengan hutang adalah suatu perikatan, misalnya menyetor sejumlah uang jaminan. Oleh karenanya memberi hutang tidak dapat diartikan sebagai memberi pinjaman uang belaka, melainkan diberi pengertian yang lebih luas sebagai membuat suatu perikatan hukum yang membawa akibat timbulnya kewajiban bagi orang lain untuk menyerahkan atau membayar sejumlah uang tertentu.Demikian juga dengan istilah utang, dalam kalimat menghapuskan piutang mempunyai arti suatu perikatan. Sedangkan menghapuskan piutang 
mempunyai pengertian yang lebih luas dari sekedar membebaskan kewajiban dalam hal membayar hutang atau pinjaman uang belaka, karena menghapuskan piutang diartikan sebagai menghapuskan segala macam perikatan hukum yang sudah ada, di mana karenanya menghilangkan kewajiban hukum penipu untuk menyerahkan sejumlah uang tertentu pada korban atau orang lain.

5) Upaya-upaya penipuan

Upaya-upaya penipuan dalam Pasal 378 KUHP ada beberapa cara, yaitu:

a) Menggunakan nama palsu

Dalam hal ini terdapat 2 (dua) pengertian nama palsu, yaitu dengan menggunakan suatu nama bukan namanya sendiri melainkan nama orang lain (misalnya menggunakan nama seorang teman) dan menggunakan suatu nama yang tidak diketahui secara pasti pemiliknya atau tidak ada pemiliknya (misalnya orang yang bernama A menggunakan nama samaran B). Nama B tidak ada pemiliknya atau tidak diketahui secara pasti ada tidaknya orang tersebut. Dalam hal ini kita harus berpegang pada nama yang dikenal oleh masyarakat luas. Misalkan A dikenal di masyarakat dengan nama $\mathrm{C}$, maka $\mathrm{A}$ mengenalkan diri dengan nama $\mathrm{C}$ itu adalah menggunakan nama palsu

b) Menggunakan martabat atau kedudukan palsu

Kedudukan palsu adalah suatu kedudukan yang disebut atau digunakan seseorang, kedudukan mana menciptakan atau memiliki hak-hak tertentu, padahal sesungguhnya ia tidak mempunyai hak tertentu itu. Jadi kedudukan palsu ini jauh lebih luas pengertiannya daripada sekedar mengaku mempunyai suatu jabatan tertentu, seperti dosen, jaksa, kepala, notaris, dan lain sebagainya. Sudah cukup ada kedudukan palsu misalnya seseorang mengaku seorang pewaris, yang dengan demikian menerima bagian tertentu dari warisan, atau sebagai seorang wali, ayah atau ibu, kuasa, dan lain sebagainya.

c) Menggunakan tipu muslihat dan rangkaian kebohongan

Dalam hal ini kedua cara menggerakkan orang lain ini samasama bersifat menipu atau isinya tidak benar atau palsu, namun dapat menimbulkan kepercayaan atau kesan bagi orang lain bahwa semua itu seolah-olah benar adanya. Namun terdapat perbedaan, yakni pada tipu muslihat berupa perbuatan, sedangkan pada rangkaian kebohongan berupa ucapan atau perkataan. Tipu muslihat diartikan sebagai suatu perbuatan yang sedemikian rupa dan yang menimbulkan kesan atau kepercayaan tentang kebenaran perbuatan itu, yang sesungguhnya tidak benar. Karenanya orang bisa menjadi percaya dan tertarik atau tergerak hatinya.

\section{B. Bentuk Perlindungan Hukum Terhadap Korban Atas Kasus Tindak Pidana Penipuan Dengan Dasar Hutang Piutang}


Hukum pada dasarnya dibuat untuk mengatur tingkah laku manusia sehingga dalam pelaksanaannya perlu adanya penegakan hukum (law enfercement).Upaya penegakan hukum pada dasarnya harus menjamin agar setiap warga Negara mematuhi hukum yang berlaku dalam masyarakat.

Terkait dengan masalah pinjam meminjam uang (hutang piutang) termasuk dalam lingkup hukum Perdata, sehingga ke ranah Pidana adalah jalan terakhir, dasar hukumnya diatur dalam Pasal 19 ayat 2 UU No. 39 tahun 1999, tentang Hak Asasi Manusia, yang berbunyi:

"Tidak seorangpun atas putusan pengadilan boleh dipidana penjara atau kurungan berdasarkan atas alasan ketidakmampuan untuk memenuhi suatu kewajiban dalam perjanjian utang piutang."

Namun jalur Pidana bisa digunakan, jika memang ada unsur penipuan sebagaimana diatur dalam Pasal 378 KUHPidana atau pun unsur Pasal tindak Pidana lainnya, seperti Pasal 372 KUHPidanayang dapat dikenakan pidana kepada pelakunya dengan sanksi pidana penjara, dan tindakan Pidana ini dilakukan dengan syarat kreditur telah melakukan penagihan beberapa kali kepada debitur

\section{Bentuk Pertanggungjawaban Pelaku Atas Tindak Pidana Penipuan Dengan Dasar Hutang Piutang}

Kebijakan hukum pidana berkaitan dengan perumusan atau perbuatan yang dianggap melanggar hukum atau nilai-nilai yang hidup dalam masyarakat ke dalam suatu peraturan perundang-undangan yang dalam ilmu hukum disebut kebijakan kriminal (criminal policy). Barda Nawawi Arief menjelaskan, kebijakan hukum pidana adalah :

Suatu konsep atau asas dalam menentukan perbuatan apa yang dilarang dan termasuk ke dalam tindak pidana, serta menentukan hukuman apa yang dapat dijatuhkan terhadap yang melakukannya. Kebijakan pencegahan adan penanggulangan kejahatan termasuk dalam kebijakan kriminal. Kebijakan kriminal sangat luas, meliputi kebijakan sosial (social policy) dan kesejahteraan sosial (social welfare policy) serta kebijakan untuk perlindungan masyarakat (social defence policy).

Kebijakan kriminal merupakan bagian dari upaya perlindungan terhadap masyarakat dan upaya mencapai kesejahteraan masyarakat. Oleh karena itu dapat dikatakan bahwa tujuan utama dari kebijakan kriminal adalah perlindungan masyarakat untuk tercapainya kesejahteraan masyarakat. Sudarto, mengemukakan tiga arti mengenai kebijakan kriminal yaitu :

1. Dalam arti sempit, adalah keseluruhan atas dan metode yang menjadi dasar reaksi terhadap pelanggaran hukum yang berupa pidana.

2. Dalam arti luas, adalah keseluruhan fungsi dari aparatur penegak hukum termasuk di dalamnya cara kerja pengadilan dan polisi.

3. Dalam arti paling luas (diambil dari Jorgan Jepsen), adalah keseluruhan kebijakan, yang dilakukan melalui perundangundangan dan badan-badan resmi 
yang bertujuan untuk menegakkan norma-norma yang sentral dari masyarakat.

Kebijakan hukum pidana berkaitan dengan masalah kriminilasasi yaitu perbuatan apa yang dijadikan tindak pidana dan penelisasi yaitu sanksi apa yang sebaiknya dikenakan pada si pelakuu tindak pidana. Penegakan hukum merupakan upaya aparat penegak hukum untuk melaksanakan nilainilai yang terjabarkan dalam kaidah hukum yang terwujud dalam bentuk tindakan untuk menciptakan, memelihara, dan mempertahankan kedamaian pergaulan hidup. Penegakan hukum sangat dipengaruhi oleh unsur-unsur dari sistem hukum,yang terdiri dari beberapa komponen yaitu substansi hukum, pranata hukum dan budaya hukum. Keseluruhan unsur-unsur sistem hukum tersenut dapat memberi pengaruh positif dan sebaliknya dapat pula memberi pengaruh negatif dalam proses penegakan hukum. Oleh karena itu, penegakan hukum bukan suatu proses logis semata, melainkan sarat dengan keterlibatan manusia di dalamnya. Penegakan hukum tidak dapat dipandang sebagai usaha deduksi yang logis, akan tetapi merupakan hasil dari pilihan-pilihan. Dengan demikian penegakan hukum tidak dapat didasarkan pada ramalan logika semata, akan tetapi juga hal-hal yang tidak menurut logika.

Korban kejahatan pada dasarnya merupakan pihak yang menderita dalam hal terjadinya suatu tindak pidana. namun sayangnya, hakhak korban dalam penegakan hukum pidana tidak memperoleh porsi dan perlindungan sebanyak yang diberikan undang-undang kepada pelaku kejahatan. Akibatnya, setelah pelaku kejahatan dijatuhi sanksi pidana oleh pengadilan, kondisi korban seringkali terabaikan, bahkan sama sekali tidak diperdulikan.

Perlindungan hukum pidana merupakan bagian dari perlindungan hukum terhadap masyarakat agar tidak menjadi korban kejahatan. Oleh karena itu, sebagai bagian dari perlindungan kepada masyarakat, maka di dalam proses peradilan pidana dalam kaitan mewujudkan perlindungan hak-hak korban dapat dilakukan dalam berbagai bentuk atau model. Beberapa bentuk atau model perlindungan yang dapat diberikan kepada korban yaitu

1. Pemberian kompensasi dan Restitusi

Setiap korban atau ahli waris dari korban tindak pidana penipuan dengan dasar hutang piutang berhak memperoleh restitusi dari pelaku. Restitusi ini merupakan ganti kerugian atas kehilangan kekayaan atau penghasilan, penderitaan, biaya untuk tindakan perawatan medis dan atau psikologis serta kerugian lain yang diderita korban. Dilihat dari kepentingan korban dalam konsep ganti rugi terkandung dua manfaat, yaitu untuk memenuhi kerugian materiil dan segala biaya yang telah dkeluarkan dan merupakan pemuasan emosional korban. Adapun dilihat dari sisi kepentingan pelaku, kewajiban mengganti kerugian dipandang sebagai bentuk pidana yang dijatuhkan dan dirasakan sebagai suatu yang konkret dan langsung 
berkaitna dengan kesalahan yang diperbuat pelaku. Selain restitusi, kompensasi terhadap korban penipuan terhadap tindak pidana dengan dasar hutang piutang merupakan bentuk lain perlindungan korban tindak pidana ssebagai ganti kerugian yang diberikan oleh Negara. Ganti kerugian oleh Negara tersebut merupakan suatu pembayaran pelayanan kesejahteraan, karena Negara bertanggungjawab dan berkewajiban secara moral untuk melindungi masyarakatnya.

1. Layanan Konseling dan Pelayanan Medis

Pelayanan konseling dan medis yang diberikan kepada korban tindak pidana dengan dasar hutang piutang, antara lain berupa pendampingan konseling, pengobatan medis dan laporan tertulis atau visum tercantum dalam Pasal 6 Ayat (1) UndangUndang Perlindungan Saksi dan Korban.

\section{Bantuan Hukum}

Berkaitan dengan proses peraadilan pidana dan untuk kepentingan hukumnya korban kejahatan memerlkukan bantuan hukum dan nasihat hukum sebagaimana jaminan hak tersebut diatur dalam Pasal 5 Ayat (1) sub n Undang-Undang Perlindungan Saksi dan Korban, pemberian bantuan hukum kepada korban diberikan dalam bentuk pendampingan yang yang lebih banyak deberikan oleh Lembaga Swadaya Masyarakat (LSM) dan Organisasi atau Lembaga pemerhati korban kejahatan, LSM berperan sebagai tempat pengaduan dan penyampaian aspirasi serta pendampingan untuk menjembatani antara korban dengan aparatur berwajib agar lebih tercipta bentuk keadilan dan perlindungan terhadap korban tindak pidana dengan dasar hutang piutang.

Bantuan hukum sangat dibutuhkan korban kejahatan sehubungan dengan keterkaitannya dengan proses peradilan pidana yang memposisikannya sebagai saksi korban sebagai satu alat bukti keterangan saksi, yang berhak memberikan keterangan tanpa tekanan dan bebas dari pertanyaan yang menjerat. Di samping itu pula bantuan hukum akan diperlukan bilama korban hendak memperjuangkan pemulihan atas kerugian yang telah dialaminya melalui pranata-pranata hukum yang ada. Penggabungan perkara gugatan ganti kerugian sebagaimana diatur dalam Pasal 98 KUHAP, dan gugatan perdata ganti kerugiatan atas dasar Pasal 1365 KUHPerdata, mengajukan permohonan ke LPSK merupakan pranata hukum yang dapat dipergunakan oleh korban kejahatan untuk mengembalikan ganti kerugian yang dideritanya. Kedua pranata hukum ini diserahkan sepenuhnya atas inisiatif korban untuk mengajukan permohonan kepada pengadilan dan untuk hal tersebut korban memerlukan bantuan dan nasihat hukum agar dapat bertindak tepat secara hukum.

3. Pemberian Informasi Kepada Korban Tindak Pidana Penipuan Dengan Dasar Hutang Piutang Mengenai Duduk Perkara dan Perkembangan Kasus 
Bekerjanya sistem peradilan pidana kejahatan harus dipandang sebagai pihak yang kedudukan dan kepentingannya harus dilindungi oleh hukum sehubungan dengan kasus yang ditangani oleh pihak yang berwajib. Seringkali korban hanya berperan dalam pemberian kesaksian baik di tingkat penyidikan maupun persidangan tetapi korban tidak mengetahui perkembangan kasus yang bersangkutan. Pemberian Informasi kepada korban tindak pidana penipuan dengan dasar hutang piutang bertujuan untuk menciptakan keterbukaan dan transparansi terhadap proses hukum yang sedang berjalan, juga bertujuan agar korban lebih jelas mengetahui bagaimana hak, kewajiban serta bentuk perlindungan yang akan didapatkan oleh korban tindak pidana penipuan dengan dasar hutang piutang tersebut.

Setelah terbitnya Undang-Undang Perlindungan Saksi dan Korban, jaminan hak korban untuk mendapatkan informasi mengenai perkembangan kasus telah diatur dalam Pasal 5 huruf F. Bahkan jika terdakwa dibebaskan, dikenakan pidana bersyarat atau bahkan mendapatkan pelepasan bersyarat, maka korban berhak untuk memperoleh ganti kerugian sebagaimana diatur dalam Pasal 7A Ayat (1) Undang-Undang Perlindungan Saksi dan Korban, yang menentukan bahwa korban tindak pidan berhak memperoleh restitusi berupa : a) ganti rugi atas kehilangan kekayaan atau penghasilan; b) ganti kerugian yang menimbulkan akibat penderitaan yang berkaitan langsung sebagai akibat tindak pidana; dan atau c) penggantian biaya perawatan medis dan/atau psikologis.

\section{KESIMPUAN}

DAN

\section{SARAN}

Berdasarkan pembahasan yang telah diuraikan di atas, maka penulis dapat menarik kesimpulan sebagai berikut :

1. Bentuk tindak pidana penipuan dengan dasar Hutang Piutang antara lain tindak pidana penipuan dalam KUHP diatur pada Buku II tentang Kejahatan terhadap Harta Kekayaan, yaitu berupa penyerangan terhadap kepentingan hukum orang atas harta benda yang dimilikinya dan tindak pidana penipuan dengan dasar hutang piutang terkait dengan masalah pinjam meminjam uang (hutang piutang) termasuk dalam lingkup hukum Perdata, sehingga ke ranah Pidana adalah jalan terakhir, dasar hukumnya diatur dalam Pasal 19 ayat 2 UU No. 39 tahun 1999, tentang Hak Asasi Manusia, yang berbunyi:“Tidak seorangpun atas putusan pengadilan boleh dipidana penjara atau kurungan berdasarkan atas alasan ketidakmampuan untuk memenuhi suatu kewajiban dalam perjanjian utang piutang". Namun jalur Pidana bisa digunakan, jika memang ada unsur penipuan sebagaimana diatur dalam Pasal 378 KUHPidana atau pun unsur Pasal tindak Pidana lainnya, seperti Pasal 372 KUHPidana yang dapat dikenakan pidana kepada pelakunya dengan sanksi pidana penjara, dan tindakan Pidana ini dilakukan dengan syarat kreditur telah melakukan penagihan beberapa kali kepada debitur. 
2. Bentuk Perlindungan Hukum terhadap korban adalah pemerian kompensasi dan restitusi, layanan konseling dan pelayanan medis, bantuan hukum serta pemberian informasi.

3. Bentuk pertanggungjawaban pelaku dalam tindak pidana penipuan dengan dasar hutang piutang adalah mengikuti prosedur yang ada, dari mulai proses penyidikan sampai proses penahanan sesuai dengan prosedur ataupun peraturan perundangundangan yang berlaku. Dan upaya penanggulangan tindak pidana penipuan dengan dasar hutang piutang bisa dengan langkah penindakan (represif) maupun dengan langkah pencegahan (preventif).

\section{B. Saran}

Adapun saran penulis menyarankan beberapa hal sebagai berikut :

1. Disarankan bentuk tindak pidana penipuan dengan dasar hutang piutang ini lebih disempurnakan agar para penegak hukum tidak salah dalam mengambil keputusan.

2. Disarankan bentuk perlindungan hukum korban tindak pidana dengan dasar hutang piutang ini lebih diperhatikan kedepannya. Karena studi mengenai kejahatan selalu akan menimbulkan korban. Dengan demikian, korban adalah partisipasi utama yang dapat menimbulkan gejala-gejala rasa takut, kesepian gelisah dan perilaku penghindaran lainnya.

3. Disarankan bentuk pertanggungjawaban pelaku tindak pidana penipuan dengan dasar hutang piutang, akim harus lebih hati-hati, tegas dan teliti dalam mempertimbangkan hal-hal yang memberatkan atau yang meringankan terdakwa. Hal tersebut untuk memberikan efek jerah dan memberikan pelajaran dan peringatan bagi masyarakat agar tidak melakukan tindak pidana. Disamping itu, juga menghindari penilain-penilaian negatif dari masyarakat terhadap sanksi yang dijatuhkan dan untuk menjaga wibawa hakim sendiri. Penuntut umum harus tegas dalam membuat surat tuntutan, terutama sanksi pidananya, tidak hanya penuntut umum, hakim juga harus tegas dalam mengambil keputusan. Karena bagaimanapun juga sanksi sangat berpengaruh dalam menurunnya atau meningkatnya angka kriminalitas yang terjadi dimasyarakat. Artinya bahwa hakim harus mampu memberikan efek jerah melalui sanksi pidana yang akan dijatuhkan. Tujuannya, bagi terdakwa untuk tidak melakukan kembali tindak pidana dan bagi masyarakat agar takut melakukan tindak pidana.

\section{DAFTAR PUSTAKA}

\section{A. Buku-Buku}

Prasetyo, Teguh, Hukum Pidana, Rajawali Pers, Jakarta: 2014.

\section{Ali, Achmad ,Menjelahi Kajian Empiris Terhadap Hukum, Kencana Prenada Media Grup, Jakarta:2012.}

Waluyo, Bambang, Pidana dan Pemidanaan, Sinar Grafika,Jakarta:2004. 
Soekanto, Soerjono, Pokok-Pokok Sosiologi Hukum, Rajawali Pers, Jakarta:2014.

B, Amran, Pengantar Tata Hukum Indonesia, Graha Kirana, Medan:2010.

Hamzah, Andi, KUHP \& KUHAP Edisi Revisi, Rineka Cipta, Jakarta:2011.

Supramono, Gatot, Perjanjian Utang Piutang, Kencana Prenadamedia Group,Jakarta:2013.

Gonggom T.P.Siregar, Hak-Hak Korban Dalam Penegakan Hukum Pidana, CV. Manhaji, Medan: 2020

\section{B. Perundang-undangan}

Undang-Undang Dasar 1945

Kitab Undang-Undang Hukum Pidana (KUHP)

Kitab Undang-Undang Hukum Acara Pidana (KUHAP)

\section{Internet}

https://cerdika.com/hukum/, diakses pada tanggal 4 agustus 2020 pukul 19.00 WIB 